\title{
Taking market crime seriously
}

\author{
Lindsay Farmer* ${ }^{\dagger}$ \\ University of Glasgow, Glasgow, UK \\ *Author e-mail: lindsay.farmer@glasgow.ac.uk
}

(Accepted 3 January 2022)

\begin{abstract}
There has been a transformation in the number and the scope of criminal laws relating to forms of market misconduct. Surprisingly, however, this area of criminal law is not one that has been systematically explored in recent writing about criminalisation. However, concepts such as white-collar crime, or financial crime, which are widely used to describe this area, are poorly defined and offer little analytic clarity. This paper argues that to take market crimes seriously it is necessary to focus on what is distinctive about markets and about market misconduct as a form of wrongdoing. This allows us to see the area as a whole and identify certain common features based on central institutional features of markets and the role that criminal law has played in protecting them - notably ensuring competition, preventing exploitation, and embedding trust. This approach, then, can be a means of raising wider questions about our understanding of the relationship between criminal law and the market in modern society - and the role that criminal law can or should play in regulating those markets.
\end{abstract}

Keywords: criminal law; criminalisation; financial crime; markets

\section{Introduction}

There has been a transformation in the number and the scope of criminal laws relating to forms of market misconduct since the 1980s. ${ }^{1}$ This wave of criminalisation began with the criminalisation of 'insider trading' in 1980, but more recently we have seen a resort to criminal law to prosecute a broader range of market misconduct, from LIBOR rigging to cartel offences, to market manipulation - as well as other forms of misconduct (such as money laundering and even bribery) which are seen as undermining the 'integrity' of markets. ${ }^{2}$ This new approach is exemplified by the EU Market Abuse Directive (2003), which stated that:

An integrated and efficient financial market requires market integrity. The smooth functioning of securities markets and public confidence in markets are prerequisites for economic growth and wealth. Market abuse harms the integrity of financial markets and public confidence in securities and derivatives. ${ }^{3}$

\footnotetext{
${ }^{\dagger}$ Funding for this research was generously provided by the Leverhulme Trust (Grant No MRF 2018-075). An earlier version of this paper was presented to the Glasgow-Edinburgh Virtual Criminal Law Group, and I am grateful to the participants for their comments. I would especially like to thank Christoph Burchard, Pamela Ferguson, Cerian Griffiths, Chloe Kennedy and Angus Young for comments on an earlier draft.

${ }^{1}$ I will be explaining what I mean by this term more fully in what follows. An initial definition would be that it is conduct (mainly, if not exclusively) in financial markets that is criminalised because it breaches norms of market conduct and has the potential to undermine public confidence in markets.

${ }^{2}$ For an overview see eg K Harrison and N Ryder The Law Relating to Financial Crime in the United Kingdom (London: Routledge, $2^{\text {nd }}$ edn, 2017).

${ }^{3}$ See https://eur-lex.europa.eu/legal-content/EN/TXT/PDF/?uri=CELEX:32003L0006\&from=en. See also Financial Markets and Services Act 2000, s 1D defining market integrity.

( $\odot$ The Author(s), 2022. Published by Cambridge University Press on behalf of The Society of Legal Scholars. This is an Open Access article, distributed under the terms of the Creative Commons Attribution licence (http://creativecommons.org/licenses/by/4.0/), which permits unrestricted re-use, distribution and reproduction, provided the original article is properly cited.
} 
Likewise, the Financial Conduct Authority website defines market integrity as 'Ensuring stability and resilience; access, effectiveness and predictability; fairness and cleanliness; and the prevention of financial crime'. ${ }^{4}$ This suggests that the 'integrity' of the market is increasingly seen as an interest to be protected by the criminal law, which would transform the relationship between the criminal law and markets, making the policing of market misconduct a more central function of the criminal law.

These developments can be seen as a response to the liberalisation or deregulation of financial markets in the 1980s which, amongst other things, created new opportunities for market misconduct. The cost of fraud alone in the UK is currently valued at figures of over $£ 100$ billion annually, and with the value of derivative trades estimated at over $€ 50$ trillion annually it is clearly important to retain confidence in markets. ${ }^{5}$ Surprisingly, however, this area of criminal law is not one that has been systematically explored in the recent wave of writing about criminalisation. 'Market' crimes are marginal to traditional areas of criminal law relating to person and property, and they are largely absent from criminal law textbooks. They are often characterised as 'regulatory' crimes or mala prohibita and thus of lesser normative significance: markets are seen as technical self-regulating institutions where the criminal law should not normally intervene. There is little examination in criminal law theory of the specificities of markets in general, or financial markets in particular, and how these might be relevant to the criminalisation of market misconduct. And when the conduct of bankers or financial traders is criminalised, there is perhaps little sympathy for them - and certainly not when compared to those marginalised individuals and groups that are commonly targeted by the criminal law. From this perspective the criminalisation of market misconduct is of little interest either in itself or for what it might offer in terms of understanding contemporary patterns of criminalisation.

In this paper I argue that market crimes are theoretically and normatively significant - in short, that criminal law should take market crimes more seriously. ${ }^{7}$ A starting point for doing this is to focus on what is distinctive about markets and about market misconduct as a form of wrongdoing. As I shall show, much of the work in this area uses concepts such as white-collar or financial crime which are poorly defined and offer little analytic clarity, grouping together offences that seem to have little in common. A focus on the market (and market crimes), I will argue, allows us to see this area as a whole and identify certain common features and issues based on central institutional features of markets and the role that criminal law has played in protecting them - as well as giving a clearer focus on questions of the value of markets and their place in our society. ${ }^{8}$ This approach, then, can be a means of raising wider questions about our understanding of the relationship between criminal law and the market in modern society - and the role that criminal law can or should play in regulating those markets.

\footnotetext{
${ }^{4}$ See https://www.fca.org.uk/markets. Its pages on financial crime make frequent reference to the duties of firms to 'ensure the integrity' of financial markets by taking various measures to prevent crime: https://www.fca.org.uk/firms/financial-crime.

${ }^{5}$ Annual Fraud Indicator 2017. Identifying the Cost of Fraud to the UK Economy, available at https://www.crowe.com/uk/ croweuk/-/media/Crowe/Firms/Europe/uk/CroweUK/PDF-publications/Annual-Fraud-Indicator-report-2017; https://www. spglobal.com/marketintelligence/en/news-insights/latest-news-headlines/uk-adopts-eu-derivatives-trading-rules-to-avoidpost-brexit-market-disruption-61936744.

${ }^{6}$ For examples of the literature on criminalisation see D Husak Overcriminalization (Oxford: Oxford University Press, 2007); A von Hirsch and AP Simester Crimes, Harms and Wrongs. On the Principles of Criminalisation (Oxford: Hart Publishing, 2011); RA Duff et al Criminalization. The Political Morality of the Criminal Law (Oxford: Oxford University Press, 2014). Certain areas of market misconduct have been looked at from the perspective of criminalisation, notably cartels (see eg C Beaton-Wells and A Ezrachi Criminalising Cartels (Oxford: Hart Publishing, 2011). However, there have been few attempts to look at the area more generally.

${ }^{7}$ I should stress that my focus is primarily on illegal conduct in legal markets, rather than illegal markets themselves. For discussion of this distinction (and the overlap between licit and illicit markets), see J Beckert and M Dewey The Architecture of Illegal Markets. Towards an Economic Sociology of Illegality in the Economy (Oxford: Oxford University Press, 2017) Introduction.

${ }^{8}$ Cf P Alldridge Relocating Criminal Law (Dartmouth: Ashgate, 2000) ch 6. For critical discussion see SP Green 'Review essay: broadening the scope of criminal law scholarship' (2001) 20 Criminal Justice Ethics 55. See also G Klass 'The law of deception: a research agenda' (2018) 89 University of Colorado Law Review 707.
} 
The paper is in three parts. In the first part I explore a range of concepts that are used to discuss criminal law in this area and show how they present difficulties when trying to think more systematically about criminalisation. In the second part I identify some significant features of markets and market misconduct that can form the basis for developing a concept of 'market crime'. The third and concluding section then shows how a concept of 'market' crime can be used to think more clearly and critically about the criminalisation of market misconduct.

\section{White-collar, financial and economic crime}

\section{(a) White-collar and corporate crime}

Perhaps the most commonly used term in this area is 'white-collar crime'. This term was famously coined by the American sociologist Edwin Sutherland in 1939 to refer to crimes committed by persons 'of respectability and high social status in the course of [their] occupation'. ${ }^{9}$ Sutherland's argument was that the crimes of the powerful were of at least equal seriousness to other crimes and that criminology as a discipline could not understand or explain crime unless it took such conduct into account. However, while few have disagreed with this general proposition, the concept of white collar crime has routinely been criticised by criminologists for its lack of clarity and intellectual coherence, factors which, arguably, give rise to even greater problems if uncritically adopted by criminal lawyers. ${ }^{10}$ The most common criticism is simply that white-collar crime lumps together a range of different types of conduct that do not have anything obviously in common and which also overlap with the same types of crime committed by non-'respectable' offenders. ${ }^{11}$ It is used to refer to property crimes, to crimes which are committed by guile or deceit, to abuse of a position of power or trust, to crimes which an offender can commit by virtue of their occupation, or even to crimes committed by corporate bodies. ${ }^{12}$ Thus, white-collar crime as a concept might refer variously to the social class of the offender, their occupation, a quality of the conduct itself or the motive for the conduct (for profit). Not only is there nothing especially 'white-collar' about some of these factors, it is not even particularly clear what some of the forms of conduct have in common. A 'respectable' person might commit an assault, or a high-status company employee might commit a crime (even a violent crime) in the course of their employment, but neither of these would normally be considered 'white-collar' without further specification. Equally, while a 'white-collar' worker might be in a position to commit certain kinds of fraud, insider dealing or to obstruct justice, it is not clear that these forms of misconduct have anything in common other than the position of the person committing them. ${ }^{13}$ There are thus two significant problems with use of the term. The first is that it confuses characteristics of the offence with those of the offender, or of the norms with the norm-breakers: just because the offender is 'respectable', it does not mean that the crime is 'white-collar. ${ }^{14}$ The second is that it is not clear what the different forms of conduct (or the laws criminalising them) have in common, if it is not some characteristic of the offender (the 'white-collar criminal'). In spite of its undoubted rhetorical appeal, it is unsatisfactory as an analytical concept.

\footnotetext{
${ }^{9}$ E Sutherland White Collar Crime. The Uncut Version (1949) (New Haven: Yale University Press, 1983) p 7. The history of the concept, and of the book, is described in the Introduction by Gilbert Geis and Colin Goff.

${ }^{10}$ For discussion of the criminological debate see J Braithwaite 'White collar crime' (1985) 11 Annual Review of Sociology 1; T Hirschi and M Gottfredson 'Causes of white-collar crime' (1987) 25 Criminology 949; S Shapiro 'Collaring the crime, not the criminal: reconsidering the concept of white-collar crime' (1990) 55 American Sociological Review 346. For discussion from a legal perspective see SP Green Lying, Cheating and Stealing. A Moral Theory of White-Collar Crime (Oxford: Oxford University Press, 2006) ch 1; SP Green 'The concept of white collar crime in law and legal theory' (2004) 8 Buffalo Criminal Law Review 1.

${ }^{11}$ See PW Tappan 'Who is the criminal?' (1947) 12 American Sociological Review 96.

${ }^{12}$ See also D Nelken 'White-collar crime' in M Maguire et al (eds) The Oxford Handbook of Criminology (Oxford: Oxford University Press, 2nd edn, 1997) ch 25.

${ }^{13}$ The examples are all taken from Green (2006), above $\mathrm{n} 10$, chs 13, 18 and 15 respectively. These same crimes can obviously be committed by non-white collar offenders, eg insider dealing where the 'insider' might be of any class or occupation (Criminal Justice Act 1993, ss 52 and 57).

${ }^{14}$ Shapiro, above n 10 , at 347 . And in general terms, the characteristics of an offender are not relevant to offence definition.
} 
There have accordingly been efforts to identify alternatives. One such alternative is the concept of corporate crime. Corporate crime is defined as the proscribed and punishable conduct of a corporation or of its representatives acting on its behalf to achieve organisational goals. ${ }^{15}$ The focus here is thus not on individuals but organisations and, in particular, on the way that organisations encourage irresponsibility (or criminality) in the pursuit of corporate goals. This is in many ways consistent with Sutherland's original project which was focused on forms of corporate wrongdoing, though conceptually the focus on organisations would mean that it is narrower than the conception of white-collar crime discussed above. Notwithstanding this, there are two problems with the use of the concept as a proxy for white-collar or market crimes. First, while it is clear that corporations do commit crimes, there is not necessarily anything distinctive about the kinds of crimes that they commit. Corporations can commit homicide, as well as range of other lesser forms of wrongdoing from environmental pollution to breach of health and safety regulations. Such conduct may or may not be for profit and may or may not be connected with markets. ${ }^{16}$ Issues in corporate crime are usually questions of corporate liability, rather than relating to matters of substantive law. Secondly, to focus exclusively on corporate wrongdoing would be to overlook the fact that some 'corporate' crimes are committed by individuals, either acting independently or using their position in an organisation. Corporate crime as a concept thus gives rise to similar problems to the concept of 'white-collar' crime. On the one hand, it is too broad, encompassing forms of conduct that have little in common other than their perpetrator, and on the other it is too narrow, failing to capture forms of wrongdoing committed by individuals using their institutional position. ${ }^{17}$

\section{(b) Financial crime}

An alternative term that is increasingly used is 'financial crime'. A typical definition can be found in the Financial Services and Markets Act 2000, s $1 \mathrm{H}$ setting out the competences of the Financial Conduct Authority. It is defined as including 'any offence involving fraud or dishonesty; misconduct in, or misuse of information relating to, a financial market; handling the proceeds of crime; or financing of terrorism'. ${ }^{18}$ On this definition financial crime is extremely broad, including four distinct, if potentially overlapping, categories of offence - though the first, third and fourth categories do not necessarily appear be forms of financial crime without further specification and the second, by specifying financial markets, is considerably more specific. This approach, though, is broadly consistent with other definitions produced by national and international bodies. Thus, the International Monetary Fund in a widely cited report from 2001 defined financial crime as 'any non-violent crime that results in a financial loss', going on to argue that this included, amongst other things, financial fraud, tax evasion and money laundering. ${ }^{19}$ A recent UK textbook on financial crime covers

\footnotetext{
${ }^{15}$ See J Braithwaite Corporate Crime in the Pharmaceutical Industry (London: Routledge \& Kegan Paul, 1984) p 6; SS Simpson 'Re-imagining Sutherland 80 years after white-collar crime' (2019) 57 Criminology 189; MH Baer 'Three conceptions of corporate crime (and one avenue for reform) two decades of corporate criminal enforcement' (2020) 83 Law and Contemporary Problems 1; JC Coffee Corporate Crime and Punishment: The Crisis of Underenforcement (Oakland CA: Berrett-Koehler, Inc, 2020). See now also Law Commission Corporate Criminal Liability. A Discussion Paper (2021), available at https://s3-eu-west-2.amazonaws.com/lawcom-prod-storage-11jsxou24uy7q/uploads/2021/06/Corporate-Criminal-LiabilityDiscussion-Paper.pdf. This is focused on questions of corporate liability which is not discussed in this paper - though it makes a similar point to the one made here, that there is no clear concept of 'corporate' crime.

${ }^{16}$ The connection with profit motive might be indirect - neglecting worker or environmental safety might be done to save money but need not be for profit. Crimes might also be committed to protect company reputation (eg by covering up a scandal), but again this is not directly for profit.

${ }^{17}$ Whether acting 'for' the company or in an individual capacity. The question of corporate or organisational involvement in 'market crime' remains of crucial importance, and I shall return to this below.

${ }^{18}$ As amended by Financial Services Act 2012, s 6. For discussion see Harrison and Ryder, above n 2, p 3. There is now also a Journal of Financial Crime that publishes papers related to the investigation and enforcement of a range of financial crimes: https://www.emeraldgrouppublishing.com/journal/jfc\#editorial-team.

${ }^{19}$ Financial System Abuse, Financial Crime and Money Laundering-Background Paper (2001), available at https://www. imf.org/external/np/ml/2001/eng/021201.htm at p 3 and Annex III.
} 
corruption and bribery, terrorist financing, market abuse and manipulation, tax evasion, and even cybercrime. $^{20}$

The principal feature of such definitions is that they are not intended to be exclusive and are often (as with the definition in the Financial Services and Markets Act) about specifying the competences of enforcement agencies. In practice, the focus of much of the literature in this area is on criminal misconduct which arises from, or is linked to, transnational markets or transnational organised crime sometimes described as forms of 'illicit capitalism'. ${ }^{21}$ The definition thus relates to policing and enforcement, rather than any qualities of the conduct. ${ }^{22}$ That said, it is not clear what is 'financial' about much of the crime thus included, or that the different types of crime have much in common with each other. Fraud is a widely drawn offence, covering a range of different ways of obtaining an advantage by means of deception; and even if the deception aims at monetary gain, or is motivated by profit (or the loss of another), we would not necessarily regard this as 'financial'. ${ }^{23}$ When the crime relates to a financial market, such as market manipulation or abuse, the term 'financial' is being used in a much more specific sense to refer to certain types of markets and their operation. And with other types of offence, such as corruption or tax evasion, it is unclear that they are 'financial' except in the sense that they involve money (in the payment of a bribe or the non-payment of taxes). There may be deception in these cases, but it need not be a constitutive element of the offence, and the victim of the offence might be a government body, or a private entity or even (on some accounts of bribery) the market which is distorted by the payment of the bribe. ${ }^{24}$ Money laundering and terrorist financing are areas of concern because financial markets are being used in a way which supports other forms of wrongdoing, but here the market is an environment in which 'illicit capitalism' can flourish and the concern is with conduct that financially supports other criminal activities. ${ }^{25}$

There have been attempts to identify shared features or characteristics of financial crime focused on the concept of trust. ${ }^{26}$ Trust is seen as relevant in three main ways. First, there is the broad sense that any crime of fraud relies on the trust of the victim: they are induced to trust that a person or state of affairs is something other than is in fact the case. Social relations rely on certain background expectations of trust in others, and the person committing the fraud might seek to exploit this expectation in some way. This might be done for money or financial gain but may be done for other reasons as well. ${ }^{27}$ Secondly, there may be an abuse of a position of trust, as where a person who is entrusted with the money, property or even information, of others - be it a banker or company director or a solicitor uses it in an unauthorised way. ${ }^{28}$ It is important to note, however, that abuse of a position of trust may be a factor in other crimes and so is not necessarily a factor unique to 'financial' crimes. ${ }^{29}$ Thirdly, some writings refer to the need to maintain trust or public confidence in markets or financial

\footnotetext{
${ }^{20}$ Harrison and Ryder, above n 2. See also P Gottschalk 'Categories of financial crime' (2010) 17 Journal of Financial Crime 441, defining financial crime as 'profit-driven crime to gain access to and control over property that belonged to someone else' (at 441) including corruption, fraud, theft and manipulation.

${ }^{21}$ See M Levi 'Preface' in B Rider (ed) Research Handbook on International Financial Crime (Cheltenham: Edward Elgar, 2015).

${ }^{22}$ Levi, ibid, $\mathrm{p}$ xxvii, argues that it is an 'administratively functional', rather than a legal, category.

${ }^{23}$ The Fraud Act 2006 (England and Wales) is unusual in limiting fraud to representations aimed at bringing about gain or loss (ss 1-5). Fraud was more widely defined at common law and in other jurisdictions. For some discussion see Rider, above n 21, Pt V.

${ }^{24}$ See Law Commission Reforming Bribery (Consultation Paper No 185) (London: HMSO, 2007) App D.

${ }^{25}$ In the case of money laundering, there would be a predicate offence (say drug- or human-trafficking) that would produce the proceeds of crime; in the case of terrorist financing the financial activity may be preparatory to the commission of further crimes. In both cases it is arguably these other crimes that taint the financial transactions.

${ }^{26}$ See for example IMF Financial System Abuse Annex III; J Horder Ashworth's Principles of Criminal Law (Oxford: Oxford University Press, $9^{\text {th }}$ edn, 2019) ch 11.

${ }^{27}$ Eg to secure consent to sexual activity. See C Kennedy 'Criminalising deceptive sex: sex, identity and recognition' (2020) Legal Studies 91 .

${ }^{28}$ See eg Fraud Act 2006, s 4.

${ }^{29}$ Eg Sexual Offences Act 2003, ss 16-24.
} 
systems - a factor which brings us closer to the idea of financial abuse. Financial abuse is defined as activities 'which have the potential to harm financial systems, [or which] exploit undesirable features of tax and regulatory systems'. ${ }^{30}$ The harm here is conceived in terms that go beyond immediate losses to individual victims; it is conduct that would undermine public trust or confidence in financial systems, and the person abusing the trust is exploiting the system rather than specific victims. This is reflected in the concept of 'market integrity' found, for example, in definitions which identify market abuse as conduct which would undermine the 'integrity' of markets and destroy public confidence in the market system. ${ }^{31}$

This focus on trust draws attention to an important feature of financial crimes, but it is still vague and of little analytical utility. The definition is over-inclusive (all frauds or abuses of trust) and does not distinguish between different kinds of trust and the role that they might play in a definition of particular financial crimes. There are important differences between interpersonal trust, trust in institutions designed to regulate certain types of activity, and trust in wider social systems or institutions (such as the market itself), and we might expect these kinds of differences to be reflected in law. Trust in a fair market, for example, is different from the decision to trust a particular individual or organisation with your financial or business affairs and is different again from trust in an emotional or personal relationship. A further criticism would be that these approaches say little about the meaning of 'financial', treating it as broadly relating to gain or loss - or even just money in general. In general terms the word finance might refer to the management of money, whether personal or public, but the word financial now has a more specific meaning relating to the business of raising and managing money in a public body or private corporation. ${ }^{32}$ Although this overlaps with what we might describe as personal finances, it is referring to a set of institutional relations and practices - financial instruments, financial institutions, or of the financial system - all of which are in turn organised around the operations of markets. This suggests that it is important to reflect on the role that markets play, and the kinds of conduct (and misconduct) that they make possible. It is, in short, hard to have a clear sense of financial system abuse without also being clear about understandings of the functions and operations of markets. The literature on financial crime refers to the consequences of this process - in terms of the opportunities that globalised financial markets offer for illicit capitalism - without engaging with the underlying processes or social phenomenon of the 'financialisation' of the economy. ${ }^{33}$

\section{(c) Economic crime}

A third term that is sometimes used is 'economic crime'. This is often treated as synonymous with financial crime (ie crimes committed for an economic motive or for gain), though in the UK Economic Crime Plan this is further glossed as crime which 'poses a threat to the UK's economy and its institutions and causes serious harm to society and individuals, ${ }^{34}$ As such, it suffers from the same problems of vagueness as the concept of financial crime.

\footnotetext{
${ }^{30} \mathrm{IMF}$, above $\mathrm{n}$ 26, p 5. It includes things that would distort markets, deter investment and trade or affect investor confidence.

${ }^{31}$ See $n 3$ above.

${ }^{32}$ 'Stripped back to its essentials, the financial system is concerned with financial intermediation, or the process through which funds are transferred from those in surplus to those in deficit and returns are achieved relative to the risk undertaken': $\mathrm{N}$ Moloney et al 'Introduction' in N Moloney et al The Oxford Handbook of Financial Regulation (Oxford: Oxford University Press, 2015) p 3.

${ }^{33}$ This refers to the 'the increasing role of financial motives, markets, actors, and institutions in the operation of economies and their environment'. See K Knorr Cetina and A Preda 'Introduction' in K Knorr Cetina and A Preda (eds) The Oxford Handbook of Sociology of Finance (Oxford: Oxford University Press, 2012) p 1. See also R Tillman 'The price is not right: financialization and financial crime' in Beckert and Dewey, above n 7, esp. at pp 288-289. See below for further discussion.

${ }^{34}$ See eg Europol definition: https://www.europol.europa.eu/crime-areas-and-trends/crime-areas/economic-crime; or the UK National Crime Agency: https://nationalcrimeagency.gov.uk/what-we-do/national-economic-crime-centre; UK Economic Crime Plan 2019-22, available at https://assets.publishing.service.gov.uk/government/uploads/system/uploads/ attachment_data/file/816215/2019-22_Economic_Crime_Plan.pdf, para 1.11.
} 
A different kind of approach to the definition of economic crime can be found in a (now classic) paper by the distinguished American criminal lawyer Sanford Kadish, which was concerned with what he described as 'economic regulatory legislation', or those regulations which 'impose restrictions upon the conduct of business as part of a considered economic policy. ${ }^{35}$ In this paper he was attempting to distinguish criminal laws which specifically regulated economic policy from other rules regulating the conduct of a business (such as health and safety laws), or criminal laws of general applicability which indirectly affected business conduct (such as fraud or embezzlement). His focus was accordingly on the use of criminal law to enforce price controls, anti-trust laws and securities regulation and so on.

This is thus not a descriptive account of economic crime, but is based on the type of conduct regulated and the nature and purpose of the regulation. The category was primarily conceived in relation to economic policy goals, or the 'preferred functioning of the economic system'. ${ }^{36}$ This in turn was described as protecting the 'economic order of the community against harmful use by the individual or his property interest'. 37 This thus explicitly distinguished between private interests, as reflected in the laws of property and contract (and as protected by general criminal laws covering theft and fraud), and the public or community interest as expressed in economic policy. As such, Kadish maintained that economic crime does not fall under traditional categories of criminal law, which are largely directed at protecting private interests (albeit conceived of as public wrongs); economic crime is aimed at protecting the collective interest in developing or pursuing a particular economic policy. ${ }^{38}$ In terms of conduct, Kadish argued that economic crimes have certain features which distinguish them from some other types of criminal conduct: they are calculative and deliberate; the misconduct is often a pattern of conduct rather than an individual act; they frequently involve group action, specifically through the corporate form; and they might attract less social stigma because of their resemblance to 'acceptable aggressive business behaviour'. ${ }^{39}$ Lastly, Kadish comments on the form of economic criminal law. Its role, he argues, is usually ancillary, either backing up other sanctions (such as licensing), or as a separate and supplementary mode of enforcement used when other sanctions fail. However, he maintained that this should not be seen as a distinct or special kind of criminal law, as many of the characteristics he identified could be found in other areas of the criminal law as well; he was rather arguing that thinking about the effectiveness of criminalisation meant attending to the specificities of the particular area. ${ }^{40}$

This approach is clearly more analytical and aimed at producing a definition which will assist not only in identifying a distinctive area of criminal law in terms of its characteristics but also in reflecting on the possible limits of the effectiveness of criminal law. I shall pick up on some elements of this approach in the next section, but it is necessary to make two comments. ${ }^{41}$ First, despite its appeal to an idea of economic policy, it is not clear that we can easily distinguish between criminal law which is related to the 'preferred functioning of the economic system' and that which is not. As Ball and Friedman showed, even an apparently straightforward example, such as the criminal laws

\footnotetext{
${ }^{35} \mathrm{~S}$ Kadish 'Some observations on the use of sanctions in enforcing economic regulations' (1963) 30 University of Chicago Law Review 423 at 424. See also H Mannheim Criminal Justice and Social Reconstruction (London: Routledge \& Kegan Paul, 1946) ss 3 and 4 .

${ }^{36}$ Kadish, ibid, at 428 .

${ }^{37}$ Kadish, ibid, at 425

${ }^{38}$ The economy in these terms is wider than the market, including production and distribution and the organisations through which these are organised: L Herzog 'Markets' in EN Zalta (ed) The Stanford Encyclopedia of Philosophy (Fall 2017, Metaphysics Research Lab, Stanford University 2017) https://plato.stanford.edu/archives/fall2017/entries/markets/, accessed 2 February 2022.

${ }^{39}$ Kadish, above n 35 , at 425 .

${ }^{40}$ It is also usually prosecuted by specialised enforcement bodies: Kadish, above n 35, at 426-427. Kadish's argument is in contrast to the common argument that since criminal law is backing up another system of sanctions it should be seen as 'regulatory' criminal law. See eg Law Commission Criminal Liability in Regulatory Contexts (CP195) (London: HMSO, 2010).

${ }^{41} \mathrm{HV}$ Ball and LM Friedman 'The use of criminal sanctions in the enforcement of economic legislation: a sociological view’ (1965) 17 Stanford Law Review 197.
} 
against cartels established by the US Sherman Act, is not so simple. ${ }^{42}$ The origins of that Act lay in the desire to address the political threat that large corporations posed to individual freedom and democracy, rather than the economic policy of preserving competition. It is thus not clear whether these laws should be included in the category of economic crimes (as defined by Kadish) because they do not have their origin in the enforcement of a 'preferred economic policy'. ${ }^{43}$ Conversely, as we have seen, criminal laws might engage with conduct that has an economic impact (eg fraud or abuse of trust) for reasons which are only indirectly related, at best, to economic policy. While Kadish is surely right in wanting to distinguish 'economic crime' from traditional categories of criminal law, there might also be reason to include some conduct covered by those traditional categories if it is primarily economic in focus. Secondly, as Kadish points out, we need to reflect on the distinctive form of criminal law in this area, specifically its relation to other kinds of regulatory strategy. ${ }^{44}$ In much of the contemporary literature this is often characterised as 'regulatory' criminal law, a terminology which is taken to imply that these laws are different from, and less morally serious, than non-regulatory criminal laws. ${ }^{45}$ However, we should not draw conclusions about the seriousness of the conduct on the basis of the character of the enforcement regime, and nor is it clear that we should characterise all misconduct in this area as regulatory simply on the basis of its relationship to policy. ${ }^{46}$ Some of this conduct might be intentionally committed and cause extreme levels of social or economic harm. Conversely, the decision to use the criminal law to pursue policy objectives does not mean that such laws are 'merely' regulatory. ${ }^{47}$ Just as importantly for my argument here, many diverse areas of conduct are 'regulated' in this sense and to focus only on the fact of regulation may lead us to ignore other important features of the conduct - specifically that it is markets that are being regulated. While the concept of regulatory crime can tell us something important about the form of certain criminal laws, it is too broad to tell us anything about the features of the conduct being regulated. So in spite of its analytical promise, the concept of economic crime is too vague to capture the relevant features of conduct in this area.

We have seen that none of these categories is entirely satisfactory. They are over- or under-inclusive and, for the most part, descriptive rather than analytical. More than this, a problem with some of these definitions is that they already assume that this area of the criminal law is different (white-collar, financial or economic) without adequately specifying the reasons for that difference, and thus offer little insight into what the criminal law ought to be protecting or how it ought to do so. One way that some of these problems might be addressed, I shall argue here, is by focusing on these as forms of 'market' crime - and engaging with features of markets that are a shared element in much of the conduct that is sought to be regulated by means of the criminal law.

\footnotetext{
${ }^{42}$ Ball and Friedman, ibid, at 202.

${ }^{43}$ ie the origins were not primarily economic, but political. Though Ball and Friedman do concede that the Act was later interpreted in terms of an aim of promoting fair competition (ibid), this illustrates the further point that the aims of a piece of legislation (economic policy or not) may change over time.

${ }^{44}$ There are other relevant features here as well: the relationship to particular regulatory fields; the relationship of penal to other sanctions (administrative/civil); enforcement by specialised agencies. See Law Commission, above n 40, Pts 1 and 2 for discussion.

${ }^{45} \mathrm{~F}$ Picinali 'The denial of procedural safeguards in trials for regulatory offences: a justification' (2017) 11 Criminal Law and Philosophy 681; H Quirk et al (eds) Regulation and Criminal Justice: Innovations in Policy and Research (Cambridge: Cambridge University Press, 2010). See now also R Williams 'Criminal law in England and Wales: just another form of regulatory tool?' in M Dyson and B Vogel (eds) The Limits of Criminal Law: Anglo-German Concepts and Principles (Intersentia, 2020) p 207.

${ }^{46} \mathrm{~N}$ Lacey 'Criminalization as regulation: the role of criminal law' in C Parker et al Regulating Law (Oxford: Oxford University Press, 2004).

${ }^{47}$ See the discussion of the criminalisation of usury in Wisconsin in order to socialise the cost of enforcement of what had previously been only a civil wrong, in Ball and Friedman, above n 41, at 213-214.
} 


\section{Constructing a concept of market crime}

In constructing a concept of market crime that can allow us to think critically about this area of the criminal law we need to look at the characteristics of the acts committed or the norms which are breached and assess whether by doing so it is possible to identify more general features of market misconduct and how it has been conceptualised. In developing this account, I will first of all set out an account of some of the central institutional features of markets to make an initial case for treating the market as the organising concept. I will then revisit the issue of trust to show how it is embedded in market practices and how this is relevant to thinking about the role of the criminal law in this area. Finally, I will discuss the moral status of market conduct, looking in particular at the question of how we might identify distinct forms of market wrongdoing.

\section{(a) Institutional features of markets}

The common feature of markets, from local food markets to complex financial markets, is that they are institutions in which parties exchange goods and services, usually through the medium of money. ${ }^{48}$ Theories of the market assume that participants are pursuing their individual self-interest to obtain the best possible bargain, which in turn means that the price of a good or service reflects demand, and in a competitive market it communicates information to participants in the market about the changing balance between supply and demand. ${ }^{49}$ Markets are thus mechanisms for distributing social goods, allowing buyers and sellers to meet and agree conditions for sale or exchange of those goods. In this sense they are also a means of co-ordinating social conduct in increasingly socially complex societies, enabling transactions and ensuring that this conduct is patterned and predictable even in the absence of centralised planning. ${ }^{50}$ This is the basis of the concept of the 'market' in economic and political thought, which generalises or aggregates particular markets or transactions to stand as either a model of how particular markets might work or to see the market as a principle of social and political organisation. ${ }^{51}$

Markets themselves may be more or less formal and more or less specialised. ${ }^{52}$ At one end of the scale they are places where goods or services are bought and sold, and where buyers and sellers meet in person. But markets may also be decentralised - we may talk about the housing market or the labour market, though this is not associated with any particular location and is a way of aggregating individual transactions to capture information about supply and demand. There are also highly specialised markets for the sale of particular commodities or securities which only exist online and where buyer and seller never meet - and indeed where buyers and sellers may have been replaced by algorithms programmed to trade when commodities reach certain prices and where those commodities might never change hands. ${ }^{53}$ In spite of such differences, all markets are usually regulated in some way: there are rules about who can participate, what can and cannot be sold, when trading can take place - and, in more specialised markets, rules may cover further conditions from the fairness of prices, to the quality of goods, to who is licensed to access the market and more. Thus, irrespective of whether or not, as Adam Smith suggested, there is a natural propensity to truck, barter and exchange, markets in modern society are complex institutions governed by extensive rules and regulations.

\footnotetext{
${ }^{48}$ Herzog, above $\mathrm{n} 38$. I am not at this point committing to any particular view about the value of markets.

${ }^{49}$ This is the basis of Pareto optimality or welfare economics.

${ }^{50} \mathrm{C}$ Taylor Modern Social Imaginaries (Durham NC: Duke University Press, 2004) ch 5; M Watson The Market (Newcastle: Agenda Publishing, 2018): 'The market concept thus calls to mind the image of a coordinating mechanism that can bring about overall systemic coherence without the need to plan that coordination into existence': $\mathrm{p} 7$.

${ }^{51}$ See L Herzog Inventing the Market. Smith, Hegel and Political Theory (Oxford: Oxford University Press, 2013); Watson, ibid.

${ }^{52}$ See Watson, above n 50, ch 2; Herzog, above n 38. See for example D Fitz-Gibbon Marketable Values: Inventing the Property Market in Modern Britain (Chicago: University of Chicago Press, 2018) on the development of the property market in Britain.

${ }^{53} \mathrm{JP}$ Pardo-Guerra 'Financial automation, past, present, and future' in Knorr Cetina and Preda (eds), above n 33.
} 
This leads economists and sociologists to talk about the 'architecture' or 'design' of markets - the conditions that establish and sustain efficient market exchange in complex markets. ${ }^{54}$ In the most basic sense it has long been acknowledged that markets depend on a stable system of property rights and a law of contract to ensure that transactions are enforceable. ${ }^{55}$ However, for markets to operate they are dependent on a range of other conditions. It must be assumed that participants in markets are 'free' - that they can choose whether or not to enter (or leave) any particular transaction, and that the outcome of the bargaining process is an expression of that free choice. ${ }^{56}$ While this can clearly be seen as an ideological claim - and is easily satirised, as in Anatole France's remark about the rich and poor being equally free to dine at the Ritz or sleep under the bridges of Paris - it is also a condition for the operation of the market. ${ }^{57}$ The process of free bargaining (or the assumption that it is free) ensures that prices present a true picture of the balance between supply and demand. Where power is used to drive a bargain it is regarded as exploitative, and it may be struck down both because it is unjust and because it distorts the market. In a related way, it is argued that markets require information to function efficiently, both because this supports individual choice and prevents exploitation, but also because it reduces search costs and makes markets more efficient. ${ }^{58}$ Lastly, it is necessary to ensure that markets are competitive, that too much power is not concentrated in the hands of certain individuals or groups (monopolistic or oligopolistic markets). Where there are asymmetries between participants - in wealth and power, or in access to information - this distorts the competitive process and the accuracy of information as reflected in prices. And the presence of competition is seen as exerting a kind of 'discipline' on market participants, preventing them from offering goods at an excessive price, or of an inferior quality, because the purchaser can move to a competitor. ${ }^{59}$

These are at best, of course, presumptions about the conditions required for markets to operate efficiently, and it is likely that few markets outside of economics textbooks meet these conditions. ${ }^{60}$ However, this focuses attention on institutional measures that are taken to prevent 'market failure' in the sense of exploitation, informational failures or anti-competitive practices. These measures might be a matter of market design - ensuring that 'markets' are constructed in a way which guards against opportunism or exploitation and ensures stable and 'efficient' outcomes. ${ }^{61}$ They might also be a matter of regulation in its broadest sense of an external body (be it the state or another regulator) intervening in the market. This can be done in different ways: legislation, consumer protection measures, the provision of subsidies, the licensing of participants and so on. Such interventions might include the use of the criminal law either by the direct criminalisation of conduct or through regulatory offences (ie criminalising conduct which breaches regulations governing a particular market). ${ }^{62}$

\footnotetext{
${ }^{54}$ Market design consists of the mechanisms that organize buying and selling; channels for the flow of information, stateset laws and regulations that define property rights and sustain contracting; and the market's culture, its self-regulating norms, codes and conventions governing behavior': J McMillan Reinventing the Bazaar. A Natural History of Markets (New York: WW Norton \& Co, 2002) p 9. There is an extensive literature on the 'architecture' and institutional features of markets. See J Beckert 'The social order of markets' (2009) 38 Theory \& Society 245; N Fligstein The Architecture of Markets (Princeton: Princeton University Press, 2001) esp ch 2; N Fligstein and L Dauter 'The sociology of markets' (2007) 33 Annual Review of Sociology 105.

${ }^{55}$ FA Hayek Law, Legislation and Liberty (London: Routledge, 1982) ch 10.

${ }^{56}$ In legal terms this is the doctrine of freedom of contract. See PS Atiyah The Rise and Fall of Freedom of Contract (Oxford: Oxford University Press, 1979); D Satz Why Some Things Should not be for Sale. The Moral Limits of Markets (Oxford: Oxford University Press, 2010) pp 21-26, discussing the link to liberal accounts of freedom and the further possible freedom-enhancing effects of markets.

${ }^{57}$ Watson, above $\mathrm{n} 50$, chs 4 and 5.

${ }^{58}$ McMillan, above n 54, ch 4, citing Kenneth Arrow: 'the biggest new concept in economics in the last thirty years, is the development of the importance of information, along with the dispersion of information' ( $\mathrm{p} 44$ ).

${ }^{59}$ Both Fligstein, above n 54, ch 2, and Beckert, above n 54, set out fuller accounts of these institutional conditions. I have focused on these elements because they are most immediately relevant to the potential use of criminal law.

${ }^{60}$ For discussion, in the context of insider dealing, see D Campbell 'Note: what is wrong with insider dealing' (1996) 16 Legal Studies 185 responding to H McVea 'What's wrong with insider dealing?' (1995) 15 Legal Studies 390.

${ }^{61}$ See eg Beckert's discussion of information economics and new institutional economics, above n 54, at 249-250.

${ }^{62}$ For a discussion see L Farmer 'The "market" in criminal law theory' Modern Law Review (forthcoming) https://doi.org/ $10.1111 / 1468-2230.12687$.
} 
The aim of such intervention is not necessarily to bring about particular outcomes, but to ensure stability or predictability of market practices and to distribute burdens and responsibilities in socially acceptable ways.

In general terms, then, we can note the importance of preventing exploitation, ensuring the free flow of information, and organising competition. But the question of how these are understood of what amounts to exploitation, which kinds of information should be available, or how competition is to be organised - and the kinds of intervention that are adopted are not themselves easily determined and must be analysed in particular institutional contexts. The framing of any particular problem (as a form of exploitation or something else) together with the kind of response adopted - particularly if criminalisation is part of the response - will then depend on particular social, political and economic conditions.

We can illustrate this by looking at two features of financial markets and how these have shaped the development of the crime of market manipulation. ${ }^{63}$ The first relates to the nature of the products which are sold on financial markets. Financial markets sell debt and credit which means that uncertainty is a controlling fact in such markets as prices are based on predictions of future returns. ${ }^{64}$ Since the deregulation of the financial industry in the 1980s, financial products have been further 'packaged' in increasingly complex and innovative instruments, such as derivatives, where what is sold is not the debt itself, but a contract related to the future value of an underlying product (often itself based on certain 'bundles' of other financial products) which allows traders to bet on movements in prices. ${ }^{65}$ While it has been argued that this allows institutions to insure against the risk of default, it is also increasingly recognised (especially in the wake of the financial crisis) that it introduces new factors of risk and complexity into financial markets. This is partly because the value of trades in derivatives vastly exceeds the value of the underlying assets, but also because the complexity of the instruments can make it difficult to assess the underlying value, which in turn makes it hard to assess the actual level of risk. ${ }^{66}$ The second key feature is the automation of trading, which has moved away from face-to-face bidding on the floors of exchanges and is increasingly conducted online using algorithms programmed to buy and sell at high speeds. ${ }^{67}$ The technology creates a new image of the market, one which 'displays its own observable trends and rules organised around the price of currencies securities and commodities' and where a particular kind of transparency is revealed through prices. ${ }^{68}$ However, increasing both the speed and volume of trading has also introduced new elements of risk into financial markets, arising both from the technology itself and from the increasing interlinked nature of the global economy. The notorious 'flash crash' of 2010, in which market indexes fell by 6 per cent in five minutes, points to the potential vulnerability of automated systems, while the ramifications of this and other 'crashes' are further magnified by the interconnectedness of global financial systems.

The institutional features of these markets create certain risks, particularly around information and value. These cannot be assessed at the level of the individual transaction, because of speed of transactions and the absence of any clear measure of value other than price. This raises particular problems of

\footnotetext{
${ }^{63}$ See generally K Knorr Cetina 'What is a financial market? Global markets as microinstitutional and post-traditional social forms' in Knorr Cetina and Preda (eds), above n 33. See also L Herzog 'Introduction: just financial markets?' in L Herzog (ed), Just Financial Markets? Finance in a Just Society (Oxford: Oxford University Press, 2017).

${ }^{64}$ JAK Galbraith The Economics of Innocent Fraud (Houghton Mifflin Harcourt, 2004). As Knorr Cetina, ibid, pp 121-122, further points out, financial contracts are not exhausted by the single transaction but endure through time, which also gives financial markets a different character from more traditional markets for products and services.

${ }^{65}$ Herzog, above n 63, pp 4-11; D Alessandrini 'Regulating financial derivatives? Risks, contested values and uncertain futures' (2011) 20 Social \& Legal Studies 441.

${ }^{66}$ For estimates of figures see M Mazzucato The Value of Everything. Making and Taking in the Global Economy (Harmondsworth: Penguin, 2018) chs 4 and 5.

${ }^{67}$ For an explanation of high-frequency trading see D Mackenzie 'Be grateful for drizzle' (2014) 36 London Review of Books (11 September); M Lewis Flash Boys. Cracking the Money Code (Harmondsworth: Penguin, 2015). See generally C Zaloom 'Traders and market morality' in Knorr Cetina and Preda (eds), above n 33, ch 9; D Mackenzie 'Zero is a clenched fist' (2007) 29 London Review of Books (1 November).

${ }^{68}$ Zaloom, ibid, pp 173-175.
} 
how market order can be maintained so that investors continue to use the market. There has accordingly been a move to the aggregate level with criminal laws that aim to protect 'market integrity' or the need to maintain confidence in the market system. ${ }^{69}$ These laws are concerned with practices that would manipulate prices or interfere with the 'proper' process of price formation in financial markets - whether by the provision of false information, the exploitation of information asymmetries or exploiting technological 'lags' in systems - and are detected by looking for irregular patterns in trades. $^{70}$ The response thus aims to bolster confidence in the market (as a system), measuring practices against an idealised conception of the perfectly competitive market. ${ }^{71}$

\section{(b) The social organisation of trust}

This brings us back to the question of trust, for we can now begin to see how trust is embedded in market practices and how certain institutional features of markets both create and mitigate problems of trust. $^{72}$

In general terms markets depend on trust. ${ }^{73}$ Any transaction that is not immediate and face-to-face, or which involves deferred delivery or payment is reliant on a degree of trust - that the seller will supply the goods ordered and that the buyer will pay. ${ }^{74}$ Such issues are multiplied in complex markets involving multiple participants or transactions, spread out geographically or involving the use of intermediaries. And the operation of systems of currency or trades in non-tangible assets (such as securities) themselves depend on trust in institutions such as banks that issue notes or guarantee value. ${ }^{75}$ While this system might seem precarious, trust, as Luhmann has argued, enables the development of social relations by (amongst other things) making possible greater social differentiation and role specification: we rely on the knowledge and expertise of others instead of having to guarantee everything for ourselves. ${ }^{76}$ However, paradoxically, 'high-trust' societies where economic development has been driven by relatively anonymous market transactions create more opportunities for fraud (or the exploitation of that trust) - which is why fraud has been described as the quintessentially 'modern' crime. $^{77}$

In complex societies the burden of deciding who or what can be trusted is not placed wholly on individuals but is socially organised. ${ }^{78}$ This is to say that trust is not only a question of individual confidence in another person, but that trust relations in markets (as in society more generally) are established and managed through a range of different informal and formal mechanisms (ongoing business

\footnotetext{
${ }^{69}$ E Herlin-Karnell and N Ryder Market Manipulation and Insider Trading (Oxford: Hart Publishing, 2019).

${ }^{70}$ See JW Williams 'Envisioning financial disorder: financial surveillance and the securities industry' (2009) 38 Economy and Society 460 .

${ }^{71}$ 'The focus ... is on market efficiency, and on the support of efficient price formation and deep liquidity': N Moloney EU Securities and Financial Market Regulation (Oxford: Oxford University Press, 2014) p 701.

${ }^{72} \mathrm{Cf}$ F Fukuyama Trust. The Social Virtues and the Creation of Prosperity (London: Hamish Hamilton, 1995), which refers in general terms to high- and low-trust societies but has little to say about the sources of trust or mechanisms which operate to create or maintain trust in commercial relationships.

${ }^{73}$ See M Granovetter 'Economic action and social structure: the problem of embeddedness' (1985) 91 American Journal of Sociology 481; J Beckert 'Trust and markets' in R Bachmann and A Zaheer (eds) Handbook of Trust Research (Cheltenham: Edward Elgar, 2006). He argues that trust is constitutive of markets if standard economic assumptions about perfect information do not hold (at p 318).

${ }^{74}$ Even face-to-face transactions require trust where the quality of the goods cannot be assessed immediately.

${ }^{75} \mathrm{G}$ Simmel The Philosophy of Money (London: Routledge, $3^{\text {rd }}$ edn, 2004). It is necessary to trust, for example, that a coin or banknote is worth a certain amount, and that other people will accept the coin at its value. See also M de Goede Virtue, Fortune and Faith. A Genealogy of Finance (London: University of Minnesota Press, 2005) Introduction; S Mihm A Nation of Counterfeiters: Capitalists, Con-Men and the Making of the United States (Cambridge, MA: Harvard University Press, 2009).

${ }^{76} \mathrm{~N}$ Luhmann Trust and Power (Chichester: Wiley, 1979) p 8.

${ }^{77}$ D Davies Lying for Money. How Legendary Frauds Reveal the Workings of Our World (London: Profile, 2018) pp 10-12 describing this as the 'Canadian paradox'. See generally E Balleisen Fraud. An American History from Barnum to Madoff (Princeton NJ: Princeton University Press, 2017) pp 23-33.

${ }^{78}$ Beckert, above $n 73$, sees these as requiring a 'willingness to engage in one-sided advance concessions' ( $p$ 326).
} 
relationships, membership of trade associations, licensing, consumer protection laws, contract law, the law of agency regulating fiduciary relationships and so on). These mechanisms might be directed at guaranteeing individual transactions, establishing longer-term relations, or ensuring the smooth and continuing operation of a particular market. They aim, in general, at inducing trust - but they also bring with them a potential for misconduct as wrongdoers might seek to exploit the very mechanisms established to guarantee trust in the first place.

This dynamic is explored in Susan Shapiro's work on agent-principal relationships in the context of financial markets. ${ }^{79}$ Principals - those wishing to trade or make an investment - rely on agents because they are unable or ill-equipped to perform certain activities themselves. An agent might have particular skills or expertise or offer access to a particular market. This is a fiduciary relationship because one person serves another but with freedom from immediate control. ${ }^{80}$ However, the relationship between principal and agent is asymmetrical - the agent has custody or control of the other's money or property, and can limit the supply of information to the principal - meaning that the principal may struggle to exercise control over the conduct of the agent. ${ }^{81}$ These problems can be exacerbated by geographical and temporal distance - for example, where the agent is in another country or is managing an investment over a period of time. In these cases, misconduct can be difficult for the principal to detect or might only come to light a considerable period of time after the original transaction. A further problem might be that in certain contexts agents are institutions, such as banks or corporations - and while these are agents in formal terms, in practice they exercise control over numbers of individual principals by virtue of their size and economic power. Notwithstanding these difficulties, principals must still rely on agents and so seek to minimise opportunities for malfeasance in various ways, such as taking care in selection, the provision of incentives, spreading risk and so on. However, there are also a range of further mechanisms which seek to address structural features of these asymmetries. ${ }^{82}$ These include such measures as the imposition of legal duties on the agent to disclose relevant information, or requirements of professional accrediting bodies around role competence and duties to account. These are in turn reinforced by second-order systems ranging from private measures (such as contracts or agency agreements) to regulatory systems (licensing, professional bodies) to the use of the criminal law in the case of egregious breaches of these duties. ${ }^{83}$ Trust, in other words, is not solely the responsibility of the parties concerned, but has been institutionalised through these other mechanisms.

These kinds of mechanisms are in part a response to general features of complex modern societies, but they also reflect and respond to certain features of modern markets - such as the widespread use of agents or the automation of trading. Traders usually have to be 'members' of exchanges, which means that they might be expelled if their conduct falls below certain standards. ${ }^{84}$ Many traders or suppliers of services have to be licensed or accredited, meaning that they should have attained certain qualifications or standards of competence. ${ }^{85}$ And certain financial markets are designated as 'regulated

\footnotetext{
${ }^{79}$ See Shapiro, above n 10. See also S Shapiro 'The social control of interpersonal trust' (1987) 93 American Journal of Sociology 623. Note that this approach differs from the conceptualisation of the principal-agent problem in economics (game theory) which is focused on devising incentives to ensure that the agent acts in the interest of the principal. This is less about trust than trying to remove the need for trust by making the agent act on grounds of rational self-interest.

${ }^{80}$ Shapiro, above $\mathrm{n} 10$, at 348 . It is fiduciary precisely because the self-interest of the agent may conflict with the interests of the principal. This is different from corporations, which employ those who act on their behalf and so operate a different mode of control - though corporations might themselves be either principal or agent to others - or conceivably both in different contexts. See below for discussion.

${ }^{81}$ This perspective is an interesting contrast to the law of agency in which, as the language of principal and agent suggests, the stress is on the primacy of the principal.

${ }^{82}$ Shapiro, above $\mathrm{n} 10$, at 350 .

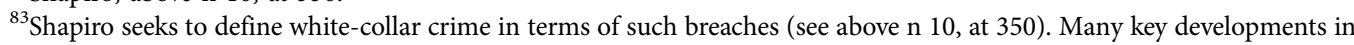
the law of property offences in the nineteenth century were aimed at problems of 'agency' as she defines them. See L Farmer Making the Modern Criminal Law. Criminalization and Civil Order (Oxford: Oxford University Press, 2016) pp 204-213.

${ }^{84}$ See eg requirements for joining the London Stock Exchange: https://www.londonstockexchange.com/trade.

${ }^{85}$ Shapiro, above n 79 , at 635-645.
} 
markets', meaning that they are subject to government controls over the operation of the market. ${ }^{86}$ This has important consequences for how we think about crimes such as fraud, which are framed in terms of breaches of trust. As a recent discussion of financial fraud points out, many contemporary market frauds are 'faceless': they rely less on face to face relations between individuals than on the opportunities afforded by institutions. ${ }^{87}$ That is to say that institutions are 'not simply contexts in which fraud occurs', but organise and facilitate certain kinds of wrongdoing. ${ }^{88}$ For example, a crime such as insider dealing which is defined as trading in a regulated market on the basis of insider information is only possible because of the prior definition of the position of the insider. ${ }^{89}$ These crimes, in short, build on prior understandings of the institutional organisation of trust and the opportunities for wrongdoing that this creates. The broader question of criminalisation this raises is that of when it is appropriate to use the criminal law to reinforce these relations.

\section{(c) The moral status of market conduct}

The remaining question to consider is that of the moral status of market conduct or how, in the light of this discussion, we might characterise forms of market misconduct for the purposes of criminalisation (that is to say, which kinds of market misconduct might be regarded as forms of public wrongs which are deserving of censure). ${ }^{90}$ This is important because moves to criminalise market misconduct have often been criticised because it is argued that market participants have not really done anything wrong, and that people are being unfairly singled out for prosecution. Those who breach the criminal law are often portrayed as 'wayward capitalists': individuals or groups who have pursued the capitalist dream but have gone astray. ${ }^{91}$ 'White-collar' crime or market misconduct is thus often seen as something which is not 'really' criminal, and which accordingly attracts less moral stigma than other more 'traditional' forms of criminal conduct. ${ }^{92}$

There are two main positions in this debate about the moral status of market misconduct. The first maintains that the market is not only self-regulating, but that it provides a kind of discipline of its own. ${ }^{93}$ In an efficient market, prices would reflect all available information about the commodities being bought and sold, thereby reducing the transaction costs for participants. ${ }^{94}$ A properly competitive market provides information not only about prices but also about the reliability or trustworthiness of buyers and sellers - such that untrustworthy or dishonest traders would be 'sanctioned' by the market by being unable to operate. Market participants must accordingly adapt their conduct - what they sell, the prices they sell at, or how they operate - to market norms or risk failure. On this view there is little place for criminal law in the fully competitive market because the market is self-disciplining and indeed to limit competition (by, for example, imposing restrictions on the kinds of information

\footnotetext{
${ }^{86}$ Markets in Financial Instruments Directive (2004/39/EC), Art 47.

${ }^{87} \mathrm{~B}$ Harrington 'The sociology of financial fraud' in Knorr Cetina and Preda (eds), above n 33, pp 401-403. See also Davies, above n 77, ch 6 .

${ }^{88}$ Harrington, ibid, p 403 (emphasis in original).

${ }^{89}$ Criminal Justice Act 1993, ss 52-60. See also Fraud Act 2006, s 4 (abuse of position offence).

${ }^{90}$ There are also well documented difficulties with the detection and enforcement of criminal law in this area. However, this is a separate issue from the question of the moral status of market misconduct. For discussion see eg D Richman 'Corporate headhunting' (2014) 8 Harvard Law \& Policy Review 265.

${ }^{91}$ S Shapiro Wayward Capitalists. Target of the Securities and Exchange Commission (New Haven: Yale University Press, 1984).

${ }^{92}$ For examples of this kind of claim see Kadish, above n 35, at 425-427; Green (2006), above n 10, ch 2. Sutherland, above n 9 , ch 4 has an interesting critical analysis.

${ }^{93}$ 'Market discipline' has a more technical meaning in banking, where it refers to measures to prevent excessive risk-taking by banks, specifically following the crisis of 2008 . However, even this usage appeals to the more general idea that the market has a 'disciplining' effect on participants. See R Bliss 'Market discipline in financial markets: theory, evidence and obstacles' in A Berger et al (eds) The Oxford Handbook of Banking (Oxford: Oxford University Press, $2^{\text {nd }}$ edn, 2014) appealing to Adam Smith's view of choice in the market (at p 571).

${ }^{94}$ McMillan, above n 54, ch 4 .
} 
available or how it might be used) would be to limit the disciplinary capacity of the market. Supporters of this view would, for example, advocate the decriminalisation of insider dealing and other forms of market manipulation, arguing that it is legitimate practice to use information from any source for a competitive advantage and that its criminalisation impairs the proper competitive functioning of the market. ${ }^{95}$ Normal market conduct, then, is to be encouraged; criminal law should be resorted to only to deal with egregious forms of wrongdoing where these bypass market norms. ${ }^{96}$

The second position is to argue that certain forms of market conduct might be wrong, and that this must be understood by reference to broader moral categories such as deception or cheating. ${ }^{97}$ The market should be seen as a kind of rule-governed game, where confidence in the market depends on participants believing that the game is being played fairly. Conduct which deceives other participants or gives some people an unfair advantage is thus seen as wrong, not only because a particular individual might be harmed, but because it destroys confidence in the market as a whole. On this view there is case for criminalising some forms of insider dealing because trading on inside information would mean that some market participants have access to information that others do not - the difficulty being, as critics point out, in establishing where the boundary might lie between legitimately and illegitimately obtained information. ${ }^{98}$

It is worth noting, though, that there are similarities between these two approaches. First, there is a shared view of markets and the benefits of competition, and merely disagreement over where the limits of the market might lie. Even the advocates of the unrestricted market concede that fraudulent activity should be criminalised - though they are somewhat vague over what exactly constitutes fraud. Secondly, both approaches have a certain abstract quality, either when discussing market exchange or moral categories such as fraud or cheating. Neither approach pays much attention to institutional structures - that is to say the actual markets where trading takes place, how these markets have been constituted and how the structures of that market shape understandings of what is, or is not, acceptable conduct. ${ }^{99}$ Mackenzie has recently shown, for example, how 'spoofing' - the practice of bidding or offering with intent to cancel the bid or offer before execution in order to try and move the price in a favourable direction - has shifted from being regarded as acceptable, even skilful, trading practice to being a criminal offence as exchanges have become automated. ${ }^{100}$ It is now argued that spoofing distorts prices, as these are now tracked through electronic monitoring systems, thus affecting the integrity of the market. ${ }^{101}$ Automation here has both reshaped understandings of the practice and expanded the capacity for detection.

The central point here is that the question of the moral status of market misconduct is neither purely a matter of economic efficiency nor moral philosophy, but that it requires detailed attention

\footnotetext{
${ }^{95}$ For the classic statement see H Manne Insider Trading and the Stock Market (New York: The Free Press, 1966). There is a review of the (extensive) literature in JP Anderson Insider Trading. Law, Ethics and Reform (Cambridge: Cambridge University Press, 2018) ch 8. See also E Fama 'Efficient capital markets: a review of theory and empirical work' (1970) 25 Journal of Finance 383.

${ }^{96} \mathrm{G}$ Becker 'Crime and punishment: an economic approach' (1968) 76 Journal of Political Economy 169; cf also Coase's understanding of cartels as practically unworkable in a perfectly competitive market. Discussed in M Furse The Criminal Law of Competition in the UK and in the US. Failure and Success (Chichester: Edward Elgar, 2012) ch 2.

${ }^{97}$ See eg Green (2006), above n 10, ch 18; McVea, above n 60; H McVea 'Supporting market integrity' in Moloney et al, above $\mathrm{n}$ 32, Pt III. The US law is framed in terms of fraud and the fiduciary duties that the 'insider' owes to the owner of the information. See Anderson, above n 95, ch 9.

${ }^{98}$ Anderson, above n 95, pp 210-213.

${ }^{99}$ Campbell, above $\mathrm{n}$ 60, at 192 : 'Exchange is only possible within the limits of an agreed and relatively fixed normative framework'.

${ }^{100} \mathrm{D}$ Mackenzie 'Spoofing: law, materiality and boundary work in futures trading' (2022) 51(1) Economy \& Society 1 . US Commodity Exchange Act, s 4c, as amended by the 2010 Dodd-Frank Wall Street Reform and Consumer Protection Act, s 747: 'It shall be unlawful for any person to engage in any trading, practice, or conduct on or subject to the rules of a registered entity that ... is, is of the character of, or is commonly known to the trade as, "spoofing" (bidding or offering with the intent to cancel the bid or offer before execution)'. The UK equivalent would be now the Financial Markets Act 2012, ss 8991.

${ }^{101}$ See Williams, above n 70
} 
to the ways that markets are constituted. And it therefore follows that in deciding whether or not market misconduct should be criminalised, it is necessary to take the market (and particular markets) as the focal point for discussion, to see how criminal law should (or should not) play a role in the design of markets.

\section{Taking market crime seriously}

We can now return to the question of how a concept of market crime can be useful in thinking about the criminalisation of market misconduct. In doing so, I will address two points: first, how my analysis can help us to understand recent developments in the criminalisation of market misconduct, and secondly to look more generally at how a focus on the market gives a clearer analytical focus to thinking about issues of criminalisation. My aim, it should be stressed, has not been to produce a 'theory' of market crime but, as a preliminary step, to try to show how the market is theoretically and normatively significant and how it is possible on this basis to develop a new kind of conceptual toolkit.

As I noted at the start of the paper, the recent growth in the criminalisation of financial misconduct is a response to the deregulation and transformation of financial markets since the 1980s and has aimed to bolster confidence in those markets through the threat of prosecution for misconduct. We are now in position to see more clearly how the offences not only reflect specific market developments, but also raise questions about the legitimacy and effectiveness of criminal law in this area. The most notable development is perhaps the increasing stress that is placed on the protection of 'market integrity'. This, as we have noted, marks a shift in the aim of the criminal law from protecting the interests of individuals (against theft or fraud) to protecting the market: the crime of market manipulation is constituted by certain specified forms of conduct which is likely to distort the market, understood in terms of interfering with the pricing mechanism of the market. ${ }^{102}$ These are new kinds of offences, defined in terms of conduct which creates the risk of certain outcomes, rather than requiring evidence of any actual outcome. This reflects the fact that, as a result of the automation of trading, in financial markets it is increasingly hard to disaggregate individual transactions and their effects. It is also the case that the focus of regulators is increasingly on irregular patterns of trading which, as Williams has argued, may be a fairly selective model - producing only a limited form of transparency. ${ }^{103}$ Market order becomes a function of the capacity to monitor, and so larger questions about legitimacy of markets and the acceptability of certain forms of conduct are elided. ${ }^{104}$ It is also the case that market 'integrity' - a concept which might be expected to fill this gap - is defined only in the vaguest terms, perhaps unwarrantably so for a concept that increasingly functions as a core concept in the criminal law in this area.

This ambiguity is plain if we look, for example at a series of FCA statements relating to prosecutions either for insider dealing or the manipulation of the LIBOR rate. Here there is reference variously to the personal 'integrity' expected of bankers, the 'integrity' of benchmarks such as LIBOR or EURIBOR, and the wider 'integrity' of the market. ${ }^{105}$ These terms are used, more or less interchangeably, without further comment or analysis - but might mean different things depending on the point of reference. For economists, 'market integrity' would appear to be a matter of efficient price formation, and therefore focused on the removal of obstacles to the free flow of information, measuring

\footnotetext{
${ }^{102}$ Herlin-Karnell and Ryder, above n 69, pp 1-4 list various attempts to define market manipulation.

${ }^{103}$ The result is a regulatory system that is adept at trolling for the relatively minor technical breaches residing close to the surface, but that is much less successful in detecting and taking action against the more systemic forms of misconduct that extend into the depths of the market': Williams, above $\mathrm{n} 70$, at 481 .

${ }^{104}$ 'The practice of financial surveillance brings into existence a particular view of both the markets and financial disorder thereby formatting the markets as not only rationalized and rule-bound, but also authorized and officially sanctioned spaces of financial consumption': Williams, above n 70, at 482. See also Mackenzie, above n 100, 14-20.

${ }^{105} R$ v Johnson (https://www.judiciary.uk/wp-content/uploads/2016/07/r-v-johnson-and-others-sentencing.pdf) para 8; https://www.fca.org.uk/publication/final-notices/barclays-jun12.pdf; https://www.fca.org.uk/news/press-releases/martin-brokers-uk-limited-fined-\%C2\%A3630000-significant-failings-relation-libor.
} 
market performance against financial modelling. ${ }^{106}$ Equally, market integrity might be measured by indexes of financial trust, which attempt to rate investor confidence. ${ }^{107}$ But there are also suggestions that market integrity might be something broader, encompassing a sense of fairness or even the 'orderliness' of the market - at least, that is to say, requiring some consideration of how the market is structured. ${ }^{108}$ The rise of market integrity signals a commitment to protecting certain markets but, as Campbell makes clear, once we question the legitimacy of insider dealing or forms of market manipulation, we must push on to question the legitimacy of these markets as markets. ${ }^{109}$ This is not just a matter of allocative efficiency (or even suppressing 'financial crime', however broadly that is conceived), but the broader question of the place of markets in society.

This leads to the second question, for if market misconduct is to be criminalised, this raises just those larger questions of when it is justifiable to use the criminal law to protect markets - and the focus on the market that I have been advocating here can offer a clearer focus in thinking about these issues than the alternatives reviewed earlier. I have argued that the institutional features of markets - those features that are designed to make the process of exchange work efficiently - can be seen as being organised around preventing exploitation, avoiding informational asymmetries, ensuring competition and embedding trust mechanisms. These are, of course, very general features. They might be institutionalised in different ways in different markets, using a range of mechanisms including both civil and criminal law, and the markets themselves might be more or less formally regulated. However, by exploring the ways that these are institutionalised in different markets at different times we can start to build up a more nuanced picture of the role that criminal law has played in constituting different markets, showing, moreover, that criminal law is not something exogenous to markets but already plays a role in constituting them. Crucially, however, by putting the market at the centre of the analysis we are able to see more specific features of what I have called 'market' crime - that is to say, what certain groups of offences have in common and how we might see a more general 'shape' to the law in this area.

This, of course, can only be a starting point, and there are number of other significant questions around criminalisation which would need to be addressed, ranging from questions of mens rea and the proof of intention (especially when dealing with corporations) to the relationship to regulatory frameworks, as well as questions of how the criminal law might be made more effective (including how it relates to administrative penalties and civil enforcement schemes). These questions cannot be answered here, but the aim has been to try and develop a theoretical framework that takes market crime seriously as a first step towards engaging with these kinds of issues. As with many other areas of the criminal law, it all too often seems that decisions about whether or not to criminalise conduct in this area are either taken 'on the hoof, in response to particular scandals or moments of crisis, or are seen as a primarily technical response to economic developments. The introduction of a new offence, or tough talk about prosecutions, is taken as an indication that financial misconduct is being addressed. However, if we are really to take market misconduct seriously, it may be necessary to begin by taking markets seriously.

\footnotetext{
${ }^{106}$ See Farmer, above n 62.

${ }^{107}$ See http://www.financialtrustindex.org/faq.htm. For critical discussion of the use of such indexes see SE Merry The Seductions of Quantification. Measuring Human Rights, Gender Violence and Sex Trafficking (Chicago: University of Chicago Press, 2010).

108“"Market integrity" is defined by the International Organization of Securities Commissions (IOSCO), as "the extent to which a market operates in a manner that is, and is perceived to be, fair and orderly and where effective rules are in place and enforced by regulators so that confidence and participation in the market is fostered" (Regulatory Issues Raised by the Impact of Technological Changes on Market Integrity and Efficiency, Final Report of the Technical Committee of IOSCO (2011))', quoted in McVea, above n 97, p 632 fn 3.

${ }^{109}$ Campbell, above n 60, at 198.
}

Cite this article: Farmer L (2022). Taking market crime seriously. Legal Studies 42, 508-524. https://doi.org/10.1017/ 1st.2022.2 